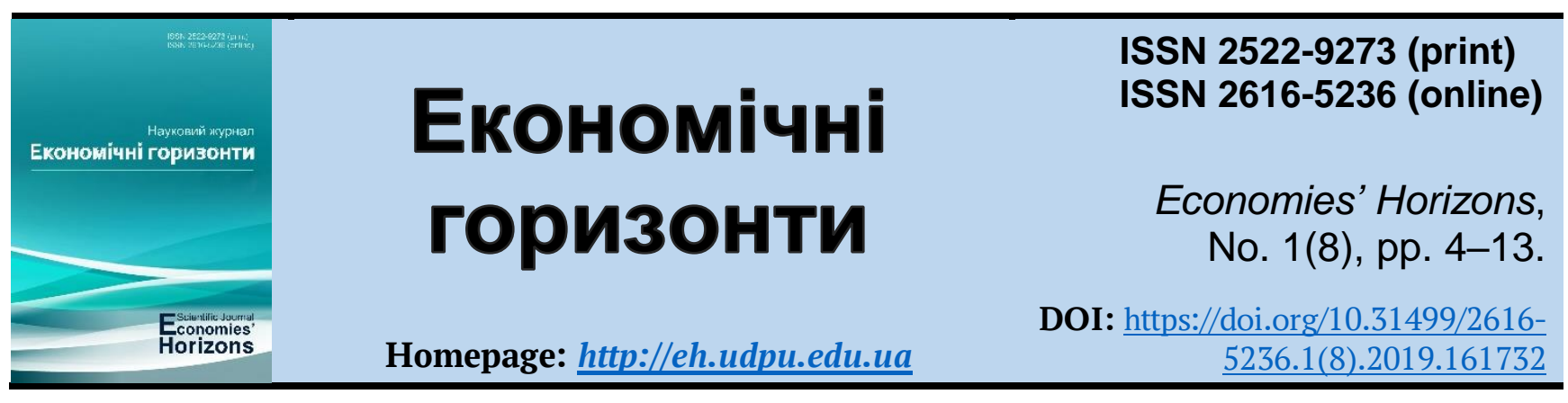

UDC 658.787

\title{
Accounting organization and presentation of information on the current assets in the enterprise statement
}

\author{
Tetyana A. Demchenko ${ }^{1}$, Cand. Ec. Sc., Associate Professor \\ Svitlana O. Mykhailovyna ${ }^{2}$, Cand. Ec. Sc., Associate Professor
}

Received: 8 February 2019

Accepted: 12 March 2019

\begin{abstract}
Demchenko, T. A. and Mykhailovyna, S. O. (2019), "Accounting organization and presentation of information on the current assets in the enterprise statement", Economies' Horizons, no. 1(8), pp. 4-13, doi: https://doi.org/10.31499/2616-5236.1(8).2019.161732.
\end{abstract}

\begin{abstract}
The purpose of the research is to study the problem aspects and methods of current assets presentation in the accounting and financial statement in order to make informed managerial decisions in the enterprise management. Methodology. In the process of writing this article various general scientific and specific research methods were used, in particular the dialectic method (in the study of economic phenomena and categories), the induction and deduction method (in the study of the current assets place in the accounting system), the historical, logical and comparison methods (at the stage of accounts specification of the current assets accounting), the systemic method (by the disclosure of the accounting organization processes of current assets), the observation method (in the process of study the state of current assets at the enterprise), the generalization and comparison method (at the stage of theoretical positions generalization and conclusions formation of this study). Results. It was established that current assets are a necessary component of the company property and require the development of an appropriate accounting system in order to provide timely information on the presence, movement and use of current assets of the enterprise. The organization of current assets accounting and presentation of information about them in the financial statements of an enterprise is complicated by the uncertainty and constant changes in the legal acts. In order to accurately present the inventory accounting of the enterprise, the accountants should timely show the economic operations on the receipt and movement of current assets in the primary accounting documents. Taking into account the direction and documentary registration of operations on the receipt and retirement of stocks, we have developed the chart of inventory behaviour at the enterprise, which clearly shows the formation of information of the accounts. The analysis of the current assets presentation in the financial statement of the enterprise has been carried out, taking into account the impact of changes since the date of the entry into force of the National P(S)A No. 1 "General requirements to financial statements". Practical meaning. The practical use of the proposed offers will ensure the correct presentation of operations on the organization of current assets accounting and the prompt receipt of the necessary information by the company management. The results of the study are aimed at improving the quality, reliability and efficiency of current assets accounting and can be used in the work of Ukrainian enterprises. Prospects for further research. Consideration of the directions of
\end{abstract}

\footnotetext{
${ }^{1}$ Pavlo Tychyna Uman State Pedagogical University; Professor at the Department of Finance, Accounting and Economic Security; ORCID ID: http://orcid.org/0000-0002-7471-540X; e-mail: demchenko.tanya7@gmail.com. ${ }^{2}$ Uman National University of Horticulture; Associate Professor at the Department of Accounting and Taxation; ORCID ID: https://orcid.org/0000-0002-1682-5790; e-mail: mihailovina@gmail.com.
} 
accounting reconciliation and taxation of operations with current assets by introducing the changes in the current statutory framework. Assessment of the accounting methods for current assets, development and implementation of recommendations for their practical improvement.

Keywords: current assets, accounting organization, primary accounting documents, financial statements, balance.

JEL Classification: M40, M41, M42

Number of references: 9; number of tables: 1; number of figures: 2; number of formulas: $\mathbf{0 .}$

\title{
Організація обліку та відображення інформації про оборотні активи у звітності підприємства
}

\author{
Демченко Т. А. ${ }^{1}$, к. е. н., доцент \\ Михайловина С. О. ${ }^{2}$, к. е. н., доцент
}

Стаття надіŭшла: 08.02.2019

Стаття прийнята: 12.03.2019

\begin{abstract}
Demchenko T. A., Mykhailovyna S. O. Accounting organization and presentation of information on the current assets in the enterprise statement. Економічні горизонти. 2019. № 1(8). C. 4-13. DOI: 10.31499/2616-5236.1(8).2019.161732.
\end{abstract}

Анотація. Мета дослідження - дослідити проблемні аспекти та методику відображення оборотних активів в бухгалтерському обліку та фінансовій звітності з метою оперативного прийняття обгрунтованих управлінських рішень керівництвом підприємства. Методологія. В процесі написання статті застосовувалися різні загальнонаукові та специфічні методи дослідження, зокрема діалектичний (при вивченні економічних явищ та категорій), індукції і дедукції (при дослідженні місця оборотних активів у системі обліку), історичний, логічний i порівняння (на стадії уточнення рахунків з обліку оборотних активів), системний (при розкритті процесів організації обліку оборотних активів), спостереження (в процесі дослідження стану оборотних активів на підприємствах), узагальнення та порівняння (на етапі узагальнення теоретичних положень і формуванні висновків з даного дослідження). Результати. Встановлено, що оборотні активи є необхідною складовою майна підприємства, і потребують створення належної системи бухгалтерського обліку 3 метою своєчасного надання інформації про наявність, рух і використання оборотних активів підприємства. Здійснення організації обліку оборотних активів та відображення інформації про них у фінансовій звітності підприємства ускладнюється невизначеністю та постійними змінами нормативно-правових актів. 3 метою правильного відображення бухгалтерського обліку запасів на підприємстві облікові працівники повинні своєчасно відображати господарські операції по надходженню і руху оборотних активів в первинних документах. Із врахуванням напрямів руху та документального оформлення операцій з надходження та вибуття запасів, нами розроблено схему руху запасів на підприємстві, що наочно показує формування інформації на рахунках бухгалтерського обліку. Проведено аналіз відображення оборотних активів у фінансовій звітності підприємства із врахуванням впливу змін з моменту введення в дію Національного П(С)БО 1 «Загальні вимоги до фінансової звітності». Практичне значення. Застосування на практиці запропонованих пропозицій дозволить забезпечити правильне відображення операцій з організації обліку оборотних активів та оперативне одержання необхідної інформації керівництвом. Результати дослідження

\footnotetext{
1 Уманський державний педагогічний університет імені Павла Тичини; професор кафедри фінансів, обліку та економічної безпеки; ідентифікатор ORCID: http://orcid.org/0000-0002-7471-540X; e-mail: demchenko.tanya7@gmail.com.

2 Уманський національний університет садівництва; доцент кафедри обліку та оподаткування; ідентифікатор ORCID: https://orcid.org/0000-0002-1682-5790; e-mail: mihailovina@gmail.com.
} 
спрямовані на покращення якості, достовірності й оперативності обліку оборотних активів, можуть бути використані в практиці роботи на підприємствах України. Перспективи подальщих досліджень. Розгляд напрямів узгодження бухгалтерського обліку й оподаткування операцій 3 оборотними активами шляхом внесення пропозицій змін у чинну нормативну базу. Здійснення оцінки діючих методів обліку оборотних активів, розробки та впровадження рекомендацій щодо їх практичного удосконалення.

Ключові слова: оборотні активи, організація обліку, первинні документи, фінансова звітність, баланс.

Кількість джерел: 9; кількість таблиць: 1; кількість рисунків: 2; кількість формул: 0.

\section{Introduction.}

The current transformation of the legislative framework significantly changed the principles and conditions of the enterprise activity. The key to stability and profitability of the enterprise is the financial firmness, ensured by an uninterrupted and continuous process of production. The enterprise efficiency directly depends on the current assets formation with the justification of their volumes, composition and characteristics of production.

Current assets are an important element of the production process, which, together with capital assets and labor resources create the preconditions for an expanded reproduction in the industrial sector of the economy. Current assets are distinguished and grouped according to the different criteria with various intention and are a prerequisite for the successful organization of accounting, since it depends on the timely and accurately dispose of current assets, the possibility of operational analysis and forecasting, the grounds of managerial decisions and ultimately a qualitative presentation of information on current assets in the enterprise reporting.

The high-quality system of accumulation and presentation of information from all accounting areas will allow simple and quick adaptation of the accountant's work to the requirements of regulatory acts, which often change. When assessing the financial and property state of an enterprise, it is necessary to obtain the information from the reporting, which, in particular, contains data about the current assets of the enterprise. It is extremely useful and informative, as it characterizes the possibility of cash flow generation in the future.

Therefore, today the special attention is paid to the organization of accounting for current assets and their presentation in the financial statement as an important element of the enterprise activity, used to control the fulfillment of project tasks, plans, analysis, forecasting, preparation of business plans.

\section{Literature review.}

In the foreign and domestic literature great attention is paid to the organization of current assets accounting of enterprises, their correct assessment, which affects the results of the enterprise and the reliability of their presentation in the statements.

V. Dubova and O. Shovkoplias (2013) consider the international and domestic interpretation of the concept of "stock", compare the presentation of information about stocks in the financial statements of enterprises in accordance with the National P(S)A No. 1 "General requirements to financial statements" and SME 1 "Presentation of financial statements" (Dubova and Shovkoplias, 2013, p. 142).

O. Horbachova and I. Oliinyk (2016) considered the main critical issues of the accounting process organization and identification the ways of improvement the organization of inventory accounting at the enterprise. The authors studied the issue of inventories assessment at the international level and the probability of use the best international experience in Ukraine (Horbachova and Oliinyk, 2016, p. 102). 
The value of inventories accounting, prerequisites and principles of its correct organization at the enterprises were investigated by one of the co-authors of this article. After examining the existing procedure for keeping inventories at the enterprise, it is proposed to implement a number of effective measures to improve the accounting process of inventories (Demchenko and Chvertko, 2017, p. 55).

Changes that took place in the form and content of financial statements of the company under the influence of international accounting and reporting standards are considered by M. Yermolaieva, Yu. Skydanenko and A. Trushyna (2017), highlighting a number of controversial issues that arise during the Balance sheet formation, including the current assets formation of the enterprise. The researchers intent to develop proposals, the implementation of which will contribute to the formation of an objective opinion on the company activities by the financial statements user necessary for the adoption of managerial decisions (Yermolayeva, Skydanenko and Trushyna, 2017, p. 206).

A number of scholars considered the theoretical background and practical aspects of the formation and effective use of current assets of agricultural enterprises. The authors form the conceptual model of the management policy of the current assets of the agricultural enterprise. The essence of the model is the organic unity of goals, principles, methods, subsystems, and information support for the implementation of the organizational and economic mechanism for the effective use of current assets. It is substantiated that the proposed components of this mechanism are not exhaustive, and their implementation is not the last stage in the system of financial management of agricultural enterprises, but only a part of the complex and multi-component policy of management of circulating assets (Ulianchenko, Vasylishyn, Yefanov and Skolotii, 2018, p. 259).

The analysis of the scientific works showed that, despite the significant scientific offers for improving the organization of accounting of current assets, there are a number of unresolved issues regarding the complete and accurate presentation of information on current assets in the financial statements of the enterprise. Taking into account the importance and relevance of the research, the above issues require new research and practical proposals.

\section{Methods.}

In the process of conducting this research various general scientific and specific research methods were used, in particular, the dialectic method (in the study of economic phenomena and categories), the induction and deduction method (in the study of the current assets place in the accounting system), the historical, logical and comparison methods (at the stage of accounts specification of the current assets accounting), the systemic method (by the disclosure of the accounting organization processes of current assets), the observation method (in the process of study the state of current assets at the enterprise), the generalization and comparison method (at the stage of theoretical positions generalization and conclusions formation of this study).

\section{Research objectives.}

To study the problem aspects and methods of current assets presentation in the accounting and financial reporting in order to make informed managerial decisions in the enterprise management.

\section{Results and discussions.}

The organization of current assets accounting is not only the internal business issues of the enterprise, but also the correctness, completeness and timeliness of tax accrual. Therefore, when studying the organization of current assets accounting it is necessary to be familiarized with the statutory instruments that directly regulate the current assets accounting. It is also necessary to consider the fact of accounting methodology inconsistency (national accounting standards) with the financial legislation.

The Law of Ukraine "On Accounting and Financial Reporting in Ukraine” of July 16, 1999 No. 996 details and clarifies the 
accounting practices. This law defines the legal principles for the implementation, regulation, organization of accounting and financial reporting in Ukraine and is applied to all legal entities, regardless of organizational and legal forms of ownership.

Undoubtedly, the function of accounting regulation is entrusted to the Ministry of Finance of Ukraine, which is mainly carried out in accordance with the approved Regulation (standard) of accounting, in which, during 1999-2019 34 Regulations (Standard) of accounting were approved.

Pursuant to the National $\mathrm{P}(\mathrm{S}) \mathrm{A}$ No. 1 "General requirements to financial statements", current assets are money and their equivalents not limited in use, as well as other assets intended for sale or use during the operational cycle or for a period of twelve months from the balance sheet date (Ministry of Finance of Ukraine, 2013).

Regulation (standard) of accounting 9 "Stocks" defines the methodological principles for the formation of inventory accounting and its disclosure in financial statements (Ministry of Finance of Ukraine, 1999).

Thus, stocks are current physical assets used in the process of production and circulation and are constantly at different stages of active transformation, starting from purchase to their use at the enterprise or implementation.

An important and significant fact is that the current assets of an enterprise are its important component of the property, which requires maximum attention to the creation of an efficient and correct accounting system in terms of the formation of complete information on the presence, movement and use of current assets.

Constant and significant changes in the legal framework require new effective approaches to solving the issues of accounting for current assets and presentation of information about them in the financial statements of the enterprise.

The enterprise should timely and correctly show the economic operations on the receipt and movement of current assets in the primary accounting documents for the reliable accounting of inventories at the enterprise.

On the basis of the study and generalization of the existing system of documenting the operations of the receipt and disposal of current assets used at the enterprises, we have diagrammed the process of inventory accounting at the enterprise (Fig. 1).

According to the National $\mathrm{P}(\mathrm{S}) \mathrm{A}$ No. 1 "General requirements to financial statements", the second section of the asset "Current assets" information on highly liquid assets is generalized. This section of the asset contains the following articles: stocks; current biological assets; receivables for goods, works, services; accounts receivable; other current receivables; current financial investments; money and their equivalents; prepaid expenses, other current assets (Ministry of Finance of Ukraine, 2013).

With the adoption of the National P(S)A No. 1 "General requirements to financial statements", radical changes took place in the form of the report, a double name was introduced and somewhat different approaches to its compilation have been observed.

Analyzing the new form of the Balance Sheet (Income Statement), we note the decrease in the obligatory (unchanged) items of the assets and liabilities. The new form of statement with the obligatory list of articles is given in Annex 1 to the National $\mathrm{P}(\mathrm{S}) \mathrm{A}$, but if there is no data before the article disclosure and it was not available in the previous reporting period, enterprises are not required to provide such information in the annual report. In case of need of the additional information disclosure, the enterprise can add articles with the appropriate name and line of code using the list of additional articles of financial statement, given in Appendix 3 of the National P(S)A. As a rule, additional lines in the Balance Sheet (Income Statement) are indicated if the information is material and the assessment of the article can be reliably determined. 


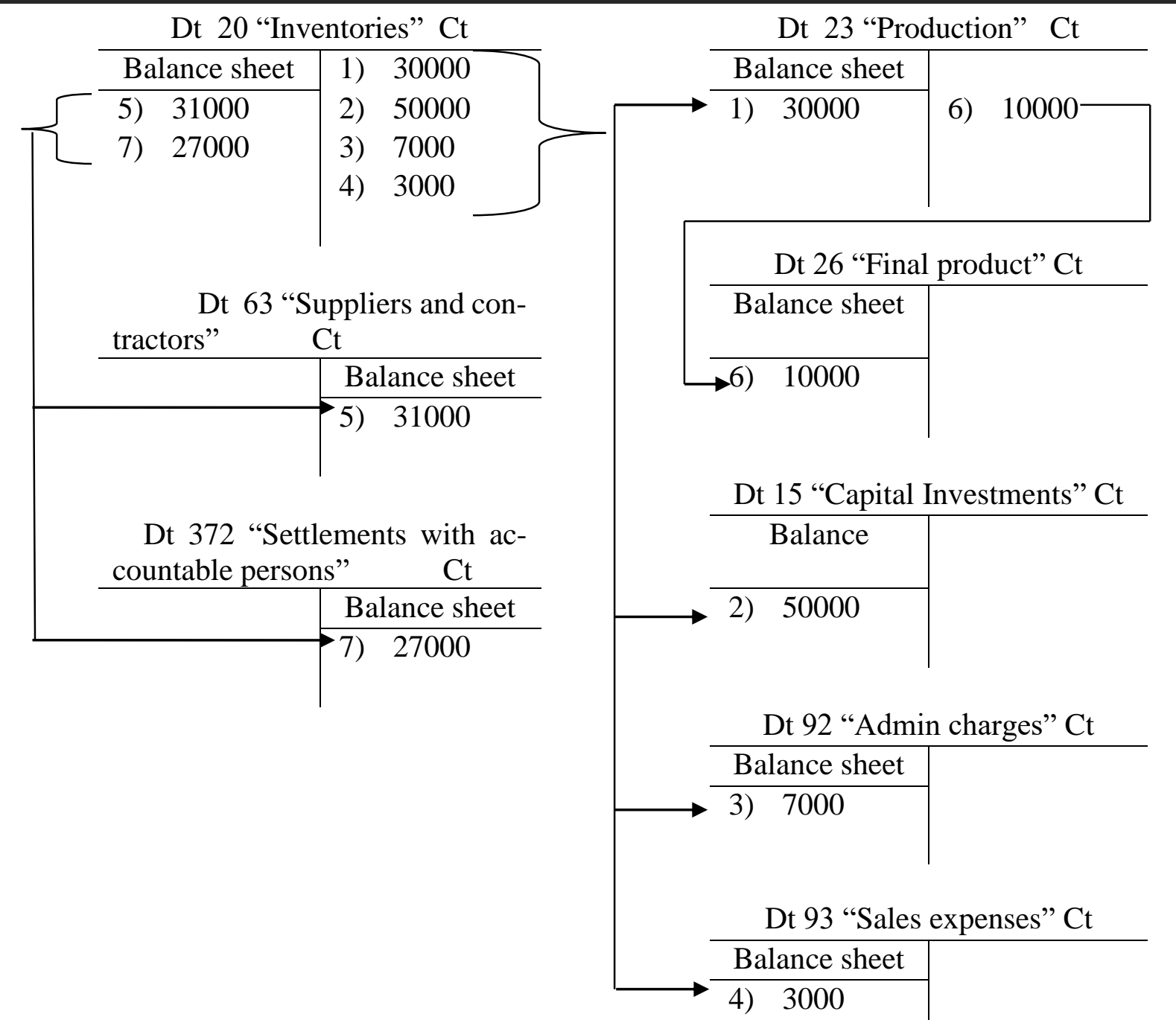

Fig. 1. The process of organization of inventory accounting at the enterprise Source: author's own developments.

Table 1 shows changes in the structure of the Section 2 "Current Assets" in the Balance Sheet (Financial Statement).

Changes in the structure of the section "Current assets" significantly influenced the indicators that are the source information for the formation, management and analysis of the composition and structure of the company current assets, which in turn created problems in analyzing the changes in current assets, where their detailed analysis is provided, depending on their distribution to certain kinds. Using the data of section II of the assets side of the balance-sheet (Financial Statement), you can determine the state of use and reserves for improving the efficiency of available current assets, formulate conclusions regarding the investment attractiveness and creditworthiness of the enterprise.

In addition, as noted by $\mathrm{O}$. Pavlenko and G. Bursuk (2017), the presence of qualitative results of analysis allows to take effective management decisions for achievement of the set goals. The authors point out that problems in the formation and use of the company property in a timely manner are revealed, and there are significant chances of deconfliction. Also, the effectiveness of using current assets will provide proper property and financial status (Pavlenko and Bursuk, 2017, p. 984).

With the adoption of the National P(S)A No. 1 "General Requirements to Financial Statements, 2013", the P(S)A 4 "Cash flow statement" which is considered one of the most complex financial statements, became invalid. 
Table 1. Changes in the structure of the Section 2 "Current Assets" in the Balance Sheet (Financial Statements)

\begin{tabular}{|c|c|c|}
\hline $\begin{array}{c}\text { Under the P(S)A } 2 \text { "Balance" } \\
\text { (cancelled) }\end{array}$ & $\begin{array}{l}\text { Under the National P(S)A No. 1, } \\
\text { "General requirements to financial } \\
\text { statements" }\end{array}$ & Additional Articles \\
\hline II Current assets & II Current assets & \\
\hline Industrial stocks (account 20,22) & Stockss $\overline{2} \overline{2}, \overline{2} \overline{2}, \overline{2}, \overline{25}, \overline{2} \overline{6,2} \overline{7}, \overline{2} \overline{8})---\rightarrow$ & $\begin{array}{l}\text { Industrial stocks (account } \\
20,22 \text { ) }\end{array}$ \\
\hline $\begin{array}{l}\text { Current biological assets (account. } \\
\text { 21) }\end{array}$ & Current biological assets (account 21) & \\
\hline $\begin{array}{l}\text { Incomplete production } \text { (account } \\
23.25 \text { ) }\end{array}$ & - - - - - - - & $\begin{array}{l}\text { Incomplete production }(\mathrm{ac}- \\
\text { count } 23.25)\end{array}$ \\
\hline Final products (account 26.27) & & $\begin{array}{lll}\text { Final products } & \text { (account } \\
26.27) & & \end{array}$ \\
\hline Goods (account 28) & 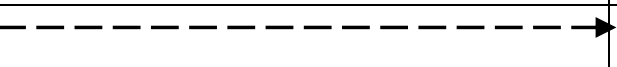 & Goods (account 28) \\
\hline Bills received (par. 34) & $---------------\rightarrow$ & Bills received (account 34) \\
\hline $\begin{array}{l}\text { Accounts receivable for goods, } \\
\text { works, services: } \\
\text { net sales value } \\
\text { initial value (account } 36 \text { ) } \\
\text { reserve of doubtful debts (account } \\
\text { 38) }\end{array}$ & $\begin{array}{l}\text { Accounts receivable for goods, } \\
\text { works, services (debts for goods, } \\
\text { works, services, adjusted for the re- } \\
\text { serve of doubtful debts (excluding } \\
\text { debt, secured by the bills, if such in- } \\
\text { formation is not given in a separate } \\
\text { line) }\end{array}$ & \\
\hline $\begin{array}{l}\text { Settlements receivable: } \\
\text { budget (account 64) } \\
\text { on issued advances (account 371) } \\
\text { from accrued income (account 373) } \\
\text { from internal calculations (ac- } \\
\text { counts 682,683.37) }\end{array}$ & $\begin{array}{l}\text { Settlements receivable: } \\
\text { budget (account } 64 \text { ) } \\
\text { including income tax }--\ldots-\ldots\end{array}$ & $\begin{array}{l}\text { Settlements receivable: } \\
\text { from accrued income (ac- } \\
\text { count } 373 \text { ) } \\
\text { from internal calculations } \\
\text { (accounts 682,683.37) }\end{array}$ \\
\hline $\begin{array}{l}\text { Other Current Accounts Receivable } \\
\text { (account } 37,63,65,66,68)\end{array}$ & $\begin{array}{l}\text { Other Current Accounts Receivable } \\
\text { (account } 37,63,65,66,68 \text { ) }\end{array}$ & \\
\hline $\begin{array}{l}\text { Current financial investments (ac- } \\
\text { count 35) }\end{array}$ & $\begin{array}{l}\text { Current financial investments (ac- } \\
\text { count 35) }\end{array}$ & \\
\hline $\begin{array}{l}\text { Cash and cash equivalents: } \\
\text { in national currency } \\
\text { 30.31) } \\
\text { in foreign currency } \\
\text { 302,312) }\end{array}$ & $\begin{array}{l}\text { Cash and cash equivalents: } \\
---------------\rightarrow\end{array}$ & $\begin{array}{l}\text { Cash (account 30) } \\
\text { Banks' accounts (account 31) }\end{array}$ \\
\hline Other current assets (account 33,643) & Other current assets (account 33,643) & \\
\hline $\begin{array}{l}\text { Prepaid expenses (account 39) Article } \\
\text { III of the distribution of assets }\end{array}$ & Prepaid expenses (account 39) & \\
\hline
\end{tabular}
ments".

Source: formed on the basis of the National $P(S) A$ No. 1 "General requirements to financial state-

According to the current National $\mathrm{P}(\mathrm{S}) \mathrm{A}$, the cash flow statement contains information on cash flows during the reporting period as a result of operational, investment and financing activities.

Form No. 3 Cash Flow Statement (Part I) is compiled according to the form No. 1 Balance Sheet (Financial Statement) and Form No. 2 Income Statement (Consolidated Income
Statement). The methodology of report preparation is logically concluded in the scheme, where the basic indicators are the prepared indicators of the balance sheet and the Income Statement (Consolidated Income Statement).

According to the current National $\mathrm{P}(\mathrm{S}) \mathrm{A}$, the distribution of cash receipts and payments in the Cash Flow Statement is divided into 
three directions - operation activity, investment and financial activity, which allows you to see the impact of each direction on cash flows, as well as the impact of cash flows on the state of affairs in each of the three directions.

One of the important innovations introduced by the National $\mathrm{P}(\mathrm{S}) \mathrm{A} 1$ is the choice of one of the proposed options for the Cash Flow Statement preparation: either directly or indirectly.

The essence of the direct method is that, in order to obtain the net cash flow indicator for the reporting period, the actual cash receipts are gradually added and the actual cash expenses are deducted.

The indirect method of determining the net cash flow takes as a basis the amount of profit (loss) of the enterprise, which is gradually adjusted for income and expenses, is not directly related to the cash flow (changes in stocks, current accounts receivable and payables, prepaid income and expenses and on the amount of gains and losses according to the results of financial and investment activities).

As a rule, the main volume of cash flow falls on operation activity. Exception is the reporting periods during which an enterprise receives or provides significant amounts of credits, loans or significant financial investment transactions, buys or sells fixed assets or other non-current assets.

Preparation of the Form 3 of the Cash Flow Statement by the direct method has several significant drawbacks in terms of informativity, namely:

- it does not present the profit of the reporting period;

- the financial standing of the company is presented to a limited extent;

- it covers not all resources of the enterprise, but only cash ones.

When completing the report by indirect method, the profit (loss) from ordinary activities before taxation is shown in the first line of the cash flow statement (line 3500), and such a report covers all the resources of the enterprise, and not only cash ones (for example in the first part, which presents the cash flow indices in operation activity). In this case, the information given in the reporting form number 3 presents not the cash flow direction either way (transfer of money for the purchase and their receipt in the form of payment), and the reasons for the change in the cash balance and their transformation into various forms of assets that, in our opinion, is very important for both the company and external users of this information. The report, prepared in such a way, proves that the accrued profit is a necessary condition (and it can be said that even a legal guarantee) to receive money.

In the Cash Flow Statement two different methods of accounting for income and expenses are used simultaneously: the accrual method and the cash method.

The use of the accrual basis implies that the input resource is a legally defined revenue, which is indicated as the first line in the income statement, and as a collection of all costs accrued upon the defrayment of expenses are considered to be the originating resource. The result of the activity in this case is measured by the difference between the recognized costs and revenues and is called the financial result. This result, using the indirect method of reporting, is given in the first line and is the starting point for determining the desired cash result.

The use of the cash method determines that the incoming resource is the receipt of money, and the originating resource are the money costs. The result of activity in this case is measured by their difference, which is called net cash flow, or net cash flow or their growth/decrease (and, importantly, is not a financial result).

The need to prepare the Cash Flow Statement is that in accounting, financial results are determined not by the cash method, but by the accrual method. This means that the recognition of income and expenses in accounting is carried out regardless of the settlements with 
buyers or suppliers (in determining the financial results of the cash method, the income would be considered actually received, and the costs actually incurred only as post-paid ones, in this case the need for the preparation of such a report would be automatically eliminated), which leads to the need to obtain additional information about the cash flows which ensure such a financial result.

The effect of the balance sheet indices on company current assets on the formation of the cash flow statement is as follows:

- the decrease of inventories in the cash flow statement is shown in the column "Receipt", which means that during the reporting period inventories for the sold products exceeded the money paid for their purchase;

- the increase of inventories is shown in the cash flow statement in the column "Expense", as this means that during the reporting period, more money was spent on their purchase than it was paid for the sold production;
- the decrease of current receivables is shown in the cash flow statement in the column "Receipt", that's why this means that the company received more money than it was accrued for receipt during the reporting period;

- the increase of current receivables is shown in the cash flow statement in the column "Expense", that's why means that the company received less money than was it was accrued for receipt during the reporting period;

- Increase or decrease in the expense items of future periods has influenced the result of cash flows, as well as increase or decrease of the balance on the current assets items (stocks and current accounts receivable). Due to this, the increase of these items is shown in the Cash Flow Statement in the column "Expense", and the decrease is given in the column "Receipt".

The influence of the above mentioned balance sheet items on the report indices is shown in Fig. 2.
Balance sheet (income statement) Assets

II. Current assets

Stocks

Current biological assets

Receivables

Prepaid expenses

Other current assets
Cash Flow Statement

I. Cash flow as a result of operation activity Increase (decrease) of current assets

For the reporting period

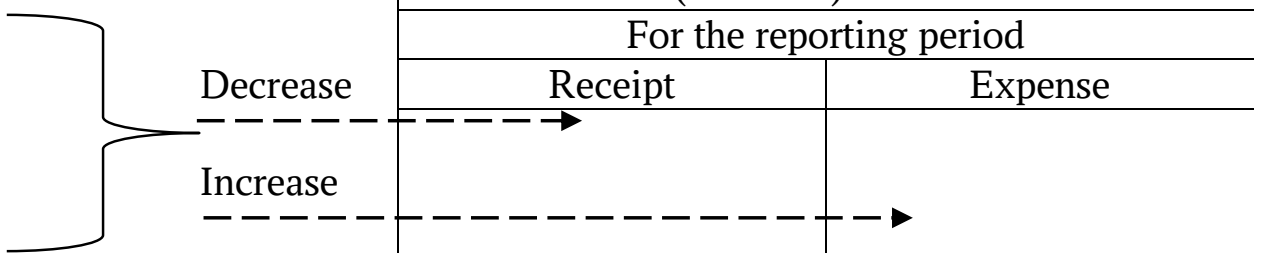

\section{Fig. 2. Schematic view of the dependence of the Cash Flow Statement indices on the bal- ance sheet items of current assets}

Source: formed on the basis of the National $P(S) A$ No. 1 "General requirements to financial statements".

The increase of the balance sheet according to the items, shown on the scheme, is shown in column 4 "Expense" of the Cash Flow Statement and, accordingly, a decrease is shown in the column 3 "Receipt". The increase of the balance of non-cash items of current assets indicates the expense of funds, therefore, correspondingly the decrease of the balance of non-cash items of current assets indicates that there was no money spending.

\section{Conclusions.}

given in the article, the following can be concluded:

1. The company engaged in the production has available current assets, because the successful production activities of the economic entity depend on the degree of current assets security. The adoption of effective managerial decisions is directly proportional to the completeness of the considered accounting and organizational aspects of current assets.

2. It was established that current assets as

Summarizing the results of the study, a necessary component of the company prop- 
erty require the establishment of an appropriate accounting system in order to provide timely information on the presence, movement and use of current assets of the company.

3. Implementation of the organization of current assets accounting and presentation of information about them in the financial statements of the enterprise is complicated by the uncertainty and constant changes in legal acts.

4. The accountants of the enterprise should timely present the economic operations on the receipt and movement of current assets in primary accounting documents in order to provide the correct accounting of inventories at the enterprise.

5. Taking into account the directions of movement and documentary registration of operations on the receipt and disposal of stocks, we have developed a chart of stock turnover at the enterprise, which clearly shows the formation of information on the bookkeeping accounts.

6. Consideration and analysis of the current assets presentation in the company accounts, taking into account the impact of changes since the date of the entry into force of National P(S)A No. 1 "General Requirements to Financial Statements".

Prospects for further research should be carried out in the direction of the assessment of current methods of current assets accounting, the development and implementation of recommendations for their practical improvement. Consideration of the directions of reconciliation of accounting and taxation of operations with current assets by introducing offers for changes in the current statutory framework.

\section{References}

Demchenko, T. A. and Chvertko, L. A. (2017), "Problems of accounting production reserves and the direction of its improvement in the enterprise", Ekonomies' Horyzons, no. 1(2), pp.48-56, doi: https://doi.org/10.31499/2616-5236.1(2).2017.112814.

Dubova, V. V. and Shovkoplias, O. O. (2013), "Reflection of reserves in the financial statements of enterprises of Ukraine according to international standards", Ekonomika i Rehion, no. 4(41), pp. 141-147.

Horbachova, O. M. and Oliinyk, I. A. (2016), "Ways to improve inventory accounting”, Bukhhalterskyi Oblik, Analiz ta Audit, no. 1(55), pp. 102-107.

Ministry of Finance of Ukraine (1999), Regulation (standard) of accounting 9 "Stocks", available at: https://zakon.rada.gov.ua/laws/show/z0751-99 (Accessed 6 February 2019).

Ministry of Finance of Ukraine (2013), National Provision (standard) of accounting 1 "General requirements to financial statements”, available at: https://zakon.rada.gov.ua/laws/show/z0336-13 (Accessed 6 February 2019).

Pavlenko, O. P. and Bursuk, H. Yu. (2017), "Financial analysis of current assets and optimization of sources of their formation", Molodyi vchenyi, no. 10(50), pp. 981-984.

The Verkhovna Rada of Ukraine (1999), The Law of Ukraine "About accounting and financial reporting in Ukraine”, available at: https://zakon.rada.gov.ua/laws/show/996-14 (Accessed 6 February 2019).

Ulianchenko, Yu. O., Vasylishyn, S. I., Yefanov, V. A. and Skolotii, I. V. (2018), "Policy improvement of formation and efficient use of the current assets of the agricultural enterprises", Financial and Credit Activity: Problems of Theory and Practice, vol.4(27), pp. 259-267, doi: http://dx.doi.org/10.18371/fcaptp.v4i27.154204.

Yermolayeva, M. V., Skydanenko, Y. D. and Trushyna, A. Y. (2017), “The annual financial report of the enterprise: the impact of international standards in its content and form", Visnyk Kharkivskoho natsionalnoho tekhnichnoho universytetu silskoho hospodarstva imeni Petra Vasylenka, vol. 185., pp. 200-215.

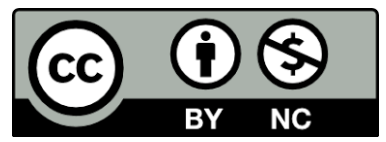

Цей твір ліцензовано на умовах Ліцензії Creative Commons «/з Зазначенням Авторства - Некомериійна 4.0 Міжнародна» (CC BY-NC 4.0). This is an open access journal and all published articles are licensed under a Creative Commons "Attribution-NonCommercial 4.0 International" (CC BY-NC 4.0). 